\title{
The Effect of Using Pay Per Click Advertisement on Online Advertisement Effectiveness and Attracting Customers in E-marketing Companies in Jordan
}

\author{
Ala' Atef Alkarablieh ${ }^{1} \&$ Hamza Salim Khraim ${ }^{2}$ \\ ${ }^{1}$ E-Business Department, Faculty of Business, Middle East University, Jordan \\ ${ }^{2}$ Faculty of Economic and Administrative Sciences, Applied Science University, Jordan \\ Correspondence: Ala' Atef Alkarablieh, E-Business Department, Faculty of Business, Middle East University, \\ Zarqa, Jordan. Tel: 962-78-762-3217. E-mail: alaa_alkarableiah@hotmail.com
}

\author{
Received: October 27, 2014 Accepted: December 10, $2014 \quad$ Online Published: January 26, 2015 \\ doi:10.5539/ijms.v7n1p180 URL: http://dx.doi.org/10.5539/ijms.v7n1p180
}

This Article is published based on a fund provided by Applied Science University.

\begin{abstract}
The study aims to explore the influence of one dimension of Search Engines which is Pay per click advertisements (PPC) on attracting customers and online advertisements effectiveness. Quantitative research analysis approach was used in collecting the data. The researchers distributed (170) questionnaires on (30) companies that using E-marketing in Jordan. The researchers received back (110) questionnaires and out of them (87) questionnaires were only usable and entered into the statistical analysis. After executing the analysis, the study concluded that using pay-per-click advertisements (PPC) has direct effect on attracting customers and online advertisements effectiveness at $(\alpha \leq 0.05)$ level at companies using E-marketing in Amman city.
\end{abstract}

Keywords: Pay Per Click (PPC), Online Advertisement effectiveness, attracting customers, Jordan

\section{Introduction}

Millions of people use search engines to find content on the Internet around the world. Search engines are web-based programs which index the web and allow people to find what they are looking for. "Search" is often used to refer to the industry that has built up around search engines. The well-known search engines include Google, Yahoo! and Microsoft's Bing. Google is the largest player globally, though dominance varies by region and is under threat from new players to the market. Search engine marketing consists of both Paid and Organic Search. Organic Search results are the primary product of a search engine. These results are the listings generally found on the left hand side on the search engine results pages (SERPs). They are not influenced by financial payment and are therefore also called natural search results. Organic search results need to be consistently reliable to attract (and keep) users. The success and growth of Google as a search engine can be attributed to its superior search algorithm which returns highly relevant organic results. The idea of Pay per click (PPC) advertising involves showing sponsored results alongside the original results. After choosing to place their advertisement on search engine, advertisers will pay when their advert is clicked on only. In addition to attracting and keeping users through original search, the main source of revenue for search engines comes from paid search. Despite the recent initiation of search engine marketing, it's considered as a new strategic communication tool on the Internet. Given the critical role of search engines on Web users' behaviors and in directing traffic to websites, many organizations have realized the importance of gaining a high position on search results pages (Feng et al., 2007). Search engine marketing (SEM) has two arms: search engine optimization (SEO) and pay per click (PPC) advertising. The Pros and Cons of SEM are presented in Table 1. 
Table 1. The pros and cons of search engine marketing

\begin{tabular}{ll}
\hline SEM: Search Engine Marketing & \\
\hline SEO: Search Engine Optimization & PPC: Pay Per Click \\
\hline PROS & PROS \\
\hline - long term ROI & - quick low cost setup \\
- high volume & - highly measurable and trackable \\
-more exposure, branding and awareness & - minimal development time required, if at all \\
\hline CONS & CONS \\
\hline - tough to quantify & - can be more expensive \\
- lots of ongoing work & - CPC is climbing \\
- results can take a while to be seen & - constant monitoring required \\
\hline
\end{tabular}

Source: Stoke, 2011.

Chaffey (2009) asserted that display ads help websites to build traffic and used to create brand awareness, familiarity, favorability and purchase intent. Interactive ads can be in graphical, text, or rich media forms such as banner, pop-up, pop-under ad, streaming media or text ads. Based on these benefits and developments in E-marketing tools, online advertisement became one of the most important sources of revenue for search engines companies (Jansen et al., 2009, Rashtchy et al., 2007). Online advertisement is currently growing faster than any other form of advertising and is expected to grow from $\$ 23.4$ billion in 2008 to $\$ 34$ billion in 2014 (Hallerman, 2009). Of this ad spending, $40 \%$ occurs on sponsored searches, in which advertisers pay to appear alongside the regular search results of a search engine. Most search engines, including tools such (Google, Yahoo, Bing and MSN...), use auctions to sell their ad space inventory. In these auctions, advertisers submit bids on specific keywords based on their willingness to PPC from a consumer searching on that keyword.

This study will be the first one to shed the light on this important and new trend in E-marketing not only in Jordan but in the whole region. After reviewing the literature, it was obvious that there is a lack of research in this particular area, and its hopefully that this study fill in this gap.

\subsection{Research Problem}

Due to intense competition, more companies seek to promote their products and services via internet to catch larger market share and hence more profits. In Jordan, only $16.2 \%$ of companies in private sector use E-marketing in its business (Ministry of IT, 2011). This can be attributed to the fact that many companies are not realizing the vital importance of E-marketing and specifically the use of search engines as a result of cognitive impairment by managers of these companies about the importance of this technology and what skills they need, and advanced knowledge. Hence this study will analyze the impact and use of one pay per click advertisement on attracting customers and online advertisement in companies that use E-marketing in Jordan. Overall, this is a comprehensive empirical investigation of PPC and its impact on the outcome of online advertisement used by search engine advertisement.

\subsection{Research Objective}

The first main goal of this research is to gain insight into the use one dimension of search engine marketing (SEM) on attracting customers and online advertisement effectiveness in E-marketing companies in Jordan by explaining the effect of using PPC advertisement on attracting customers and online advertisement in companies using E-marketing in Jordan.

\section{Literature Review}

\subsection{Online Advertisement Effectiveness}

According to (Tellis, 2009) online advertising effectiveness is a very broad concept that generally refers to market response to an organization's advertising. The primary objective of search engine advertising is improving visibility of a websites on search engines and attracting more web traffic from search engines to those websites (Karjaluoto and Leinonen, 2009). In other words, search engine is mainly responsible for directing more web traffic to a website. After that, it is the responsibility of the website owner (i.e., the business/advertiser) to convert this traffic to purchasing behavior or other financial results. Therefore, we consider web traffic a reflection of advertising effectiveness and we define search engine advertising effectiveness as the extent to which businesses believe that their SEA strategy has been helpful in attracting more traffic to their website through improving their visibility in search engine result. Effectiveness of advertising has been measured in different technique, such as the number of clicks on the ad, users' perceptions of advertisements, users' attitudes 
towards brand, purchase intention, recall and recognition of components of the advertisement (Keng \& Lin, 2006). While $\mathrm{Wu}$ et al. (2008) investigated the measures for advertising effectiveness and he found that brand attitude, effect recall, click through, and customer's purchase intentions are the most common factors.

\subsection{Pay Per Click (PPC)}

GoTo.com, was the first company to introduce pay per click onto the Internet in 1998. The idea was that sponsored versions of the search term would be auctioned off to the highest bidder. Beginning in 2000 Goto.com started selling their services to many of the largest search engines. In 2002, Google began offering the paid search results on other search engines. During 2002 Google signed several major partnership deals, agreeing to serve sponsored search results for Earthlink, AskJeeves, and America Online (Sullivan \& Chris, 2004). Despite entering the game a little later, the revenue generated from Google's PPC program would help Google grow to a company with a market cap of well over 100 Billion dollars (Sullivan, 2005).

The main idea behind PPC advertising on search engines is that advertiser pays only for each click on their advertisement. PPC advertising continues to evolve, and formats available range from simple text adverts through to Flash banners and even video adverts. PPC advertising revolutionized the online advertising industry, and today, PPC advertising generates $99 \%$ of Google's revenue. Google reported revenues of $\$ 8.44$ billion for the quarter ended December 31, 2010, an increase of 26\% compared to the fourth quarter of 2009. Given that PPC is a non-intrusive form of advertising it has become a popular advertising technique on the Internet nowadays. It involves a company displaying its ads on various search engines, where the company pays the owners of those search engines every time a user clicks on one of their ads. Visitors click on the ads out of genuine interest therefore this form of advertising is said to generate a much better success rate than the traditional pay per impression methods such as banners, or pay per view based advertising (Drolias, 2007). When comparing the online advertising channels: search engine optimization, social media and pay per click, it was found that pay per click through channels such as Google AdWords can be relatively easy to implement and can achieve immediate results in the form of getting visitors to see your website within minutes.

The current leader in the pay per click space is Google AdWords (Jerkovic, 2009) and when going to the front page of Google AdWords one is presented with testimonials of small businesses having huge success by buying traffic from Google. The platform is in a sense presented out to be an efficient and cost effective way for small businesses to acquire new customers. If a business sees that there is little or no traffic coming to their site they could be entertained to the possibility of using a pay per click platform such as Google AdWords to give them an extra traffic boost.

\subsection{PPC Mechanism}

According to Stoke, (2011, p. 290) PPC advertising is used for a number of channels and platforms. Quite simply, the advertiser pays when a user clicks on an advert. PPC advertising is usually run as an auction model, so advertisers place bids to appear based on certain criteria. The advertising platform determines when adverts are eligible to appear and serves them as appropriate. The advertiser then pays the advertising platform when their advert is clicked on.

With PPC advertising, the advertiser:

- Creates the copy for an advertisement.

- Determines the landing page for the advert.

- Selects the keywords or criteria for which that advertisement should appear.

- Chooses the maximum amount they are willing to pay for a click on the advert or per 1000 impressions (CPM).

The advertising platform:

- Checks the advert for compliance to editorial guidelines.

- Displays the advert for relevant search queries or other criteria.

- Determines the rank of the advert based on the advertiser's maximum bid and the relevance of the advert (which includes factors such as click through rate (CTR), and ad copy, keyword and landing page relevance).

Research has concluded many advantages when advertisers use PPC. One of the leading advantages of pay per click for advertisers is that it is without doubt the fastest way of driving traffic to your site (Chapman, 2011). While on the other hand, SEO campaign can take months for the benefits to surface, with pay per click advertising your advertisement will appear on search results pages as soon as your pay per click campaign goes live. Another advantage for PPC advertising that it provide you with flexibility in designing and controlling your 
campaign based on the nature and needs of your business. Furthermore, you can organize your PPC Advertisements to appear over a certain period of time in the year, for example a seasonal campaign. In terms of number of customers clicking your advertisement, you can bid only the amount that you are willing to pay based on the targeting option you choose and by setting daily and monthly budgets. It gives you flexibility by allowing you to track the performance of your pay per click campaign.

You can also choose to target your advertisements to a particular position or pay more for certain keywords at certain times of the day or week. You can decide how much you want to pay for keywords and for other bidding options, such as increased traffic, to meet your marketing goals. There are no fees for placing an advertisement on the results page of a search engine. This means you will still be generating awareness of your brand but it might not cost you anything. After a click on a PPC Advertisement, a customer may then save your URL onto their computer and come back to your site later. They might even forward the link to a friend. PPC Advertising also allows you to target your advertisements so they only appear to qualified customers. Targeting options can be based on language, location, demographics targeting by gender and age, as well as time of the day and day of the week targeting, allow you to hone in on the audience that is most likely to turn a click into a conversion. PPC also puts all businesses on a level playing field. A small business has just as high a chance of winning at a keyword bid and placing high on a search engine results page as a large company when they choose keywords specific to their advertisement, optimize their PPC Advertising Campaign and landing page and take advantage of the targeting tools. Table 2 shows the environments where PPC advertisement can appear in.

Table 2. Environments where PPC advertisement can appear in

\begin{tabular}{lllll}
\hline PPC Advert Type & $\begin{array}{l}\text { Where Adverts are } \\
\text { Displayed }\end{array}$ & Types of Adverts & Example Networks & Targeting \\
\hline Search & $\begin{array}{l}\text { Search Engine results } \\
\text { pages }\end{array}$ & $\begin{array}{l}\text { Text adverts, ad } \\
\text { extensions, some images } \\
\text { Contents sites, e.g. news } \\
\text { Text adverts, banner } \\
\text { sites or blogs }\end{array}$ & $\begin{array}{l}\text { Google, Adwords, } \\
\text { Microsoft, AdDynamo } \\
\text { Google, Adwords, } \\
\text { media, video adverts } \\
\text { AdDynamo }\end{array}$ & $\begin{array}{l}\text { Keywords and content, } \\
\text { behavioral, topics, } \\
\text { categories, demographics } \\
\text { Social Network }\end{array}$ \\
& $\begin{array}{l}\text { Social networks e.g. Face } \\
\text { book or You tube }\end{array}$ & $\begin{array}{l}\text { standard image, some } \\
\text { banner adverts, video } \\
\text { advert } \\
\text { Text and banners }\end{array}$ & $\begin{array}{l}\text { Face book, You tube, } \\
\text { Linkedin }\end{array}$ & $\begin{array}{l}\text { Demographics, } \\
\text { Keywords }\end{array}$ \\
& Search Engine Display & Adwords & $\begin{array}{l}\text { Keywords and content, } \\
\text { behavioral, topics, } \\
\text { categories, demographics }\end{array}$ \\
\hline
\end{tabular}

Source: Stoke, 2011, p. 291.

Based on the above presented literature, this research will propose the following hypotheses:

$\mathrm{H}_{01}$ : There is a statistical significant effect of Pay-per-click advertisement on online advertising effectiveness in E-marketing companies in Jordan at $(\alpha \leq 0.05)$ significance level.

$\mathrm{H}_{02}$ : There is a statistical significant effect of Pay-per-click advertisement on online advertising effectiveness in E-marketing companies in Jordan at $(\alpha \leq 0.05)$ significance level.

\section{Previous Studies}

Despite the importance of PPC advertisement, it's quite obvious that there is a dearth in research done concerned PPC advertisement locally and internationally. In fact this study is considered as the first one not only in Jordan but even in the Middle East. The first study was done by Fjell, (2008) and aim to determine how the advertiser choice between pay-per-view (PPV) and pay-per-click (PPC), when a web publisher is a price taker in the market for advertising banners, and the number of visits is decreasing in advertising. The main results for this study: The web publisher should choose PPV (PPC) if the click-through rate is lower (higher) than the ratio of the PPV to PPC market prices. Indeed, pursuing this one recommendation, combined with a trial-and-error approach for level of advertising, will result in optimal profitability.

The same author Fjell (2010) conduct another study and designed to analyze the choice of pay-per-view (PPV) and pay-per-click (PPC) under imperfect competition where a web publisher is a price setter in the market for advertising banners, the number of visit to the website is decreasing in advertising, and the click-through rate is constant. The main results for this study: The optimal amount of advertising under pure PPV or PPC pricing is 
decreasing in market power, and smaller than for a price-taking web publisher. If the web publisher sells both PPV and PPC advertising, then the ratio of the PPV to PPC prices should equal the click-through rate if the market power is the same in both markets. However, if the market power for PPV advertising exceeds that for PPC advertising, then the ratio of the PPV to PPC prices should also exceed the click-through rate.

While the aim of Singh et al., (2011) research was to evaluate the impact of SEO on the advertisement of firms. The sample size for the research is 100 managers from different IT companies of north India. The results of this research show that search engine optimization affects the advertisement and sales. Most of the people use the search engines like Google, MSN etc for searching for products or services and more than $90 \%$ people select the product from first page only and more than $80 \%$ select the product or services from first three or four pages. The companies who are using the SEO for the purpose of advertisement are getting more new customer than the companies using the other methods.

Whereas Fabiola Igna, (2012) study provide a better understanding on the effectiveness of online marketing communication tools (SEO, PPC), Online PR, Online Partnership, Online Ads, E-Mail Marketing, and Viral Marketing on attracting customers. These tools can be successful in leading for positive outcomes and attracting new visitors to the website if adopted correctly, And discovered that "entertaining" and "trustworthy" are the most important attributes in online communication and will make any B2C communication successful. The results provided by this study show that Search Engine Optimization tool has scored high by respondents, while Search Engine Marketing can attract customers through trust and convenience. In general, SEM tools were the most favorable attributes by respondents who described SEM as trustworthy, reliable, and not time consuming and informative.

\section{Methodology}

This research is based on quantitative method that use questionnaire to collect data. The questionnaire consisted of four sections and contained 26 questions. The first section of the questionnaire gathered demographic information on the respondents and their companies. The remaining three parts consisted of scale items that utilize a 5-point Likert type scales. The anchors included: strongly disagree to strongly agree. According to Telecommunication and IT ministry in Jordan, the total number of companies that use E-marketing is 77 companies. The researchers contacted those companies to participate in this study, after one month only 30 company out of 77 agree to take part in this research. Based on some respondents' request, hard copy of the questionnaire was distributed by hand. Some respondents' requested to fill in the questionnaire online, which was distributed over the Internet via company mailing lists and social networking websites. The sample consist from people who are directly involved in E-marketing and PPC ad, such as E-Marketer, Web Designer, Programmer, Software Engineering and System Analysis. The process of collecting data took almost two months. Out of the 170 surveys that were sent out, 110 choose to take part in the study. Only (87) questionnaires were usable and entered into the statistical analysis. This yielded a response rate of $64 \%$.

\subsection{Reliability Test (Cronbach's Alpha)}

Reliability test was used to test the consistency and suitability of the measuring tools. If Alpha Coefficients were above 0.80 , they were considered high, and if they were above 0.75 , they were accepted, Table (3) shows that Cronbach's alpha for variables were above the accepted level.

Table 3. Cronbach's alpha for research variables

\begin{tabular}{lll}
\hline Variable & No. of Items & Cronbach's alpha \\
\hline Pay Per Click (PPC) & 10 & 0.845 \\
$\begin{array}{l}\text { Advertisement } \\
\text { Attracting Customers online }\end{array}$ & 5 & 0.801 \\
$\begin{array}{l}\text { Online Advertisement } \\
\text { effectiveness }\end{array}$ & 5 & 0.790 \\
\hline
\end{tabular}

\subsection{Validity}

To avoid validity problems in our study we have taken measures to avoid confusion. We choose only respondents/companies who have earlier experience in E-marketing and online business and all of the respondents were either Marketing mangers, IT Managers, Website Designer, Programmer and System analysts who are actively using internet and online services in their companies. 


\section{Study Sample Characteristics}

As shown in table 4, majority of the sample was male (81.6\%). Respondents were predominantly with less than (5) years experience. Over (67.8\%) of companies are small size (less than 100 employee) and only (33.5\%) of them are using E-marketing in high level. About (28.7\%) of the respondents were specialized in E-marketing while approximately (35.6\%) of companies with annual income less than $100.000 \mathrm{JD}$.

Table 4. Demographic profile of the respondents

\begin{tabular}{|c|c|c|}
\hline Demographics & Frequency & Percentage $\%$ \\
\hline \multicolumn{3}{|l|}{ Gender } \\
\hline Male & 71 & 81.6 \\
\hline Female & 16 & 18.4 \\
\hline Total & 87 & $100 \%$ \\
\hline \multicolumn{3}{|l|}{ Years of experience in the company } \\
\hline $1-5$ years & 41 & 47.2 \\
\hline $6-10$ years & 28 & 32.2 \\
\hline $11-15$ years & 15 & 17.2 \\
\hline More than 16 years & 3 & 3.4 \\
\hline Total & 87 & $100 \%$ \\
\hline \multicolumn{3}{|l|}{ Job Title } \\
\hline E-Marketer & 25 & 28.7 \\
\hline General Manager & 14 & 16.2 \\
\hline Web Designer & 10 & 11.5 \\
\hline Programmer & 12 & 13.8 \\
\hline Software Engineering & 20 & 23.0 \\
\hline System Analysis & 3 & 3.4 \\
\hline Total & 87 & $100 \%$ \\
\hline \multicolumn{3}{|l|}{ Company Size (Employee no.) } \\
\hline Small Size (less than 100) & 59 & 67.8 \\
\hline Medium size (101 and less than 500) & 15 & 17.3 \\
\hline Large Size (more than 501) & 13 & 14.9 \\
\hline Total & 87 & $100 \%$ \\
\hline \multicolumn{3}{|c|}{ Degree of using E-marketing by company } \\
\hline Low & 22 & 25.3 \\
\hline Medium & 5 & 5.7 \\
\hline High & 31 & 35.6 \\
\hline Extremely high & 29 & 33.4 \\
\hline Total & 87 & $100 \%$ \\
\hline \multicolumn{3}{|l|}{ Company Annual Online sales Volume } \\
\hline Less than $100.000 \mathrm{JD}$ & 31 & 35.6 \\
\hline 100-500JD Thousand & 28 & 32.2 \\
\hline 501.000 - 1 Million JD & 8 & 9.2 \\
\hline More than 1 Million JD & 20 & 23.0 \\
\hline Total & 301 & $100 \%$ \\
\hline
\end{tabular}

\subsection{Descriptive Statistics}

To get the general results of the study, the means and the standard deviations of different responses to the statements were calculated using Statistical Package for Social Sciences (SPSS). While the standard mean of all statements is above (3), the response below is considered as positive. 
Table 5. Mean, standard deviation, level of importance of Pay Per Click items

\begin{tabular}{lllll}
\hline No. & Using Pay Per Click Advertising (PPC) has & Mean & St. D & Level of Importance \\
\hline 1 & $\begin{array}{l}\text { Achieve quick results for the company } \\
\text { Contributed significantly in achieving the } \\
\text { company goals when we use it }\end{array}$ & 4.05 & 0.861 & High \\
High
\end{tabular}

Table 6. Mean, standard deviation, level of importance of attracting customers

\begin{tabular}{lllll}
\hline No. & Attracting customers Online & Mean & St. D & Level of Importance \\
\hline 1 & $\begin{array}{l}\text { Using E-marketing and social media tools } \\
\text { such as Search Engine Marketing, } \\
\text { Facebook, email, etc., contributed in } \\
\text { attracting new customers }\end{array}$ & 4.09 & 0.816 & High \\
& $\begin{array}{l}\text { The company offers secure and safe } \\
\text { electronic payment for its customers }\end{array}$ & 3.94 & 0.881 & High \\
& $\begin{array}{l}\text { The company advanced electronic } \\
\text { infra-structure has helped in achieving its } \\
\text { goals }\end{array}$ & 3.67 & High & High \\
& $\begin{array}{l}\text { Customers were attracted to the company } \\
\text { due to use of international standards in its } \\
\text { e-store } \\
\text { Customers were attracted to the company } \\
\text { due to innovative tools in launching new } \\
\text { products and services to online customer }\end{array}$ & 3.61 & 0.932 & High \\
5 & & 0.901 & \\
\hline
\end{tabular}

Table 7. Mean, standard deviation, level of importance of online advertising

\begin{tabular}{lllll}
\hline No. & Online Advertising Effectiveness & Mean & St. D & Level of Importance \\
\hline 1 & $\begin{array}{l}\text { The company can largely control the } \\
\text { online ad text through the amendment to } \\
\text { the content }\end{array}$ & 4.10 & 0.822 & High \\
\hline $\begin{array}{l}\text { Online advertising can be presented in } \\
\text { different formats, such as the introduction } \\
\text { with sound effects }\end{array}$ & 4.09 & 0.725 & High \\
3 & $\begin{array}{l}\text { Online advertising enables the company to } \\
\text { communicate with customers online }\end{array}$ & 3.99 & 0.958 & High \\
\hline & $\begin{array}{l}\text { Online advertising raise the level of the } \\
\text { company's brand in the market } \\
\text { Online advertising raise the level of the }\end{array}$ & 3.86 & 0.780 & High \\
\hline
\end{tabular}




\subsection{Hypotheses Testing}

To test the hypotheses, a simple regression analysis was used to analyze the relationship between the Pay per click advertisements (PPC) and its impact on attracting customers as well as online advertisements. Therefore to achieve the research objectives, this section will test the formulated hypotheses as follows:

Table 8 . Model summary

\begin{tabular}{lllll}
\hline Model & $\mathrm{R}$ & $\mathrm{R}$ Square & Adjusted R Square & Std. Error of the Estimate \\
\hline 1 & $.418^{\mathrm{a}}$ & .174 & .155 & .5361 \\
\hline
\end{tabular}

${ }^{\text {a }}$ Predictors: (Constant), Attracting Customers Online, Online Advertisement.

Table 9. ANOVA results for independent and dependent ${ }^{\mathrm{b}}$ variables

\begin{tabular}{lllllll}
\hline Model & & Sum of Squares & df & Mean Squares & F & Sig \\
\hline 1 & Regression & 5.104 & 2 & 2.552 & 8.878 & $.000^{\mathrm{a}}$ \\
& Residual & 24.144 & 84 & .287 & & \\
& Total & 29.247 & 86 & & & \\
\hline
\end{tabular}

${ }^{\text {a }}$ Predictors: (Constant), Attracting Customers Online, Online Advertisement.

${ }^{\mathrm{b}}$ Dependent Variable: PPC.

To test the first hypothesis, simple regression analysis was conducted as shown in table 10 .

Table 10. Results of simple regression aAnalysis of PPC variable against online advertisement

\begin{tabular}{llllllllll}
\hline & \multicolumn{10}{c}{ Regression coefficient } \\
\hline $\mathrm{DV}$ & $\mathrm{R}^{2}$ & $\mathrm{~F}$ & $\mathrm{D} . \mathrm{F}$ & $\mathrm{Sig}$ & $\mathrm{ID}$ & $B$ & $\mathrm{SE}$ & $\mathrm{T}$ & $\mathrm{Sig}$ \\
\hline $\begin{array}{l}\text { Online } \\
\begin{array}{l}\text { Advert } \\
\text { Effectiveness }\end{array}\end{array}$ & 0.142 & 7.576 & 1 & 0.007 & PPC & 0.317 & .115 & 2.752 & 0.007 \\
\hline
\end{tabular}

The results of the simple regression analysis that regress the PPC advertisement variables against online advertisement are shown on table (10). It shows that the PPC advertisement variable explained $14 \%$ percent of the variance, where $\left(\mathrm{R}^{2}=0.14, \mathrm{~F}=7.576\right.$, Sig. $\left.=0.000\right)$. Therefore, the null hypothesis is rejected and the alternative hypothesis is accepted, which states that the Pay-per-click advertisement affects online advertising in E-marketing companies in Jordan at $(\alpha \leqslant 0.05)$

Once again simple regression analysis was conducted to test the second hypothesis as shown in table 11.

Table 11. Results of simple regression analysis of PPC Variable against attracting customers online

\begin{tabular}{llllllllll}
\hline & & \multicolumn{7}{c}{ Regression coefficient } \\
\hline DV & $\mathrm{R}^{2}$ & $\mathrm{~F}$ & $\mathrm{D} . \mathrm{F}$ & $\mathrm{Sig}$ & $\mathrm{ID}$ & $B$ & $\mathrm{SE}$ & $\mathrm{T}$ & $\mathrm{Sig}$ \\
\hline $\begin{array}{l}\text { Attracting } \\
\begin{array}{l}\text { Customers } \\
\text { Online }\end{array}\end{array}$ & 0.169 & 17.277 & 1 & 0.007 & PPC & 0.556 & .134 & 4.157 & 0.000 \\
& & & & & & & & & \\
\hline
\end{tabular}

From table 11, the researchers observe that there is a significant effect of Pay per click advertisement on attracting customers online. The $\mathrm{R}^{2}$ was $(0.169)$, this means the $(0.169)$ of attracting customers online changeability's results from the changeability in Pay per click advertisement. As $\beta$ was $(0.556)$, this means the increase of one unit in Pay per click will increase customer attractiveness value (0.258). Confirms significant effect F Calculate was (17.277) and its significance at level $(\alpha \leq 0.05)$ and that confirms valid second hypotheses, and thus we accept the hypothesis.

\section{Conclusion}

The purpose with this study is to find out the effect of using Pay-per-click advertisement on attracting customers and online advertisement effectiveness in companies using E-marketing in Jordan. Online advertising, especially 
search engine advertising has quickly become vital for businesses to succeed in e-marketing. Google, the largest search engine, provides its traditional pay-per-click in addition to other services such as site-targeted ads to advertisers. In spite of the fact that more and more companies are using these techniques internationally, very little research has attempted to analyze how companies can make use of this new type of ads in Jordan. This research will help in spotting the light and filling the gap regarding PPC advertisement in E-marketing companies in Jordan. Results show that there a statistical significant effect of using pay-per-click advertisement on attracting customers online at the significance level $(\alpha \leq 0.05)$ in companies that use E-marketing in the Jordan, and this means that this usage contributes to the attraction more visitors and increase traffic on the website for the company. Another result presented by this research show that there is a statistically significant effect of using pay-per-click advertising on the online ads effectiveness at the significance level $(\alpha \leq 0.05)$ in companies that use E-marketing in Jordan. This means that they contribute to the promotion of products and services better for the company via the Internet and thus will lead to increased profits and return on investment ROI, and this hypothesis is consistent with the study (Johansson, 2012). Furthermore, descriptive results show that the use of pay-per-click advertisement have contributed in raising the level of the company's brand as well as the ability of targeting particular geographical area, and also contributed in increasing the number of the Keywords of the company web site.

\section{Managerial Implications}

Based on the above obtained results the researchers will propose the following managerial implications for E-marketing companies in Jordan. It's obvious that there are a limited number of E-marketing companies that use PPC in Jordan and in order to increase the number, companies need to improve and update its infrastructure as well as using advanced and fast servers with adequate safety and affordable cost. E-marketing companies should focus on search engines which use search engine marketing and search engine advertisement to get the best results. Therefore it's highly recommended to use Yahoo search engine to achieve the utmost results. It's imperative to hire a competent and trained programmers and web designers to work online to fulfill the desires of consumers, while providing information about current and new product and services. E-marketing companies needs to maintain a detailed data base on customers that click on their advertisement and if possible to know why. Furthermore, companies needs to provide additional online services such as e-payment through websites as well as options for product and service delivery. Finally, companies must realize that more ads generate more revenue but may turn viewers off. We suggest putting fewer ads on websites and more content, and get compensated for by future profits.

\section{References}

Chaffey, D. (2009). E-business and e-commerce management: strategy, implementation and practice. GB, Pearson Education.

Drolias, B. (2007). Pay-Per-Click: The Complete Guide. London: Lulu.

Efendioglu, A., \& Igna, F. (2012). Attracting Customers Online Effectiveness of Online Marketing Tools. Un published Master thesis. Luleå University of Technology, Sweden.

Feng, J., Bhargave, H. K., \& Pennock, D. M. (2007). Implementing sponsored search in web search engines: conceptual evaluation of alternative mechanism. Informs Journal of Computing, 19, 137-148. http://dx.doi.org/10.1287/ijoc.1050.0135

Fjell, K. (2009). Online advertising: pay-per-view versus pay-per-click a comment. Journal of revenue and pricing management, 8(2/3), 200-206. http://dx.doi.org/10.1057/rpm.2008.39

Fjell, K. (2010). Online advertising: pay-per-view versus pay-per-click with market power. Journal of revenue and pricing management, 9(3), 198-203. http://dx.doi.org/10.1057/rpm.2010.5

Jansen, B. J., Flaherty, T. B., Baeza-Yates, R., Hunter, L., Kitts, B., \& Murphy, J. (2009). The Components and Impact of Sponsored Search. Computer, 42, 98-101. http://dx.doi.org/10.1109/MC.2009.164

Jerkovic John, I. (2009). SEO Warrior. Published by O'Reilly.

Johansson, M. (2012). Paid Traffic Pay per click advertising in Swedish companies (Master Thesis). University of Gothenburg, Gutenberg: Sweden.

Karjaluoto, H., \& Leinonen, H. (2009). Advertisers' perceptions of search engine marketing. International Journal of Internet Marketing and Advertising, 5, 95-112. http://dx.doi.org/10.1504/IJIMA.2009.021952

Keng, C. J., \& Lin, H. Y. (2006). Impact of telepresence levels on internet advertising effects. CyberPsychology \& Behavior, 9, 82-94. http://dx.doi.org/10.1089/cpb.2006.9.82 
Ministry of IT. (2011). Published at AlRai Daily News paper, Amman Jordan. Retrieved from http://www.alrai.com/article/4354.html

Palanisamy, R. (2013). Evaluation of Search Engines: A Conceptual Model and Research Issues. International Journal of Business and Management, 8(6). http://dx.doi.org/10.5539/ijbm.v8n6p1

Rashtchy, S., Kessler, A. M., Bieber, P. J., Schindler, N. H., \& Tzeng, J. C. (2007). The user revolution: the new advertising ecosystem and the rise of the internet as a mass medium. Piper Jaffray.

Singh, S., Sharma, G., \& Singh, P. (2011). Impact of search engine optimization on the advertisement. Retrieved from http://ssrn.com/abstract $=1831120$

Stokes, R. (2011). The essential Guide to digital marketing (4th ed.). London: Quirk.

Sullivan, D. (2005). "Yahoo to Buy Overture". Search Engine Watch. Retrieved from $\mathrm{http}: / /$ searchenginewatch.com/searchday/article.php/2234821

Sullivan, D., \& Sherman, C. (2004). "Search Engine User Attitudes". Search Engine Watch. Retrieved from http://searchenginewatch.com/searchday/article.php/3357771

Tellis, G. J. (2009). Generalizations about Advertising Effectiveness in Markets. Journal of advertising research, 49, 240-245. http://dx.doi.org/10.2501/S0021849909090357

Wu, S. I., Wei, P. L., \& Chen, J. H. (2008). Influential factors and relational structure of Internet banner advertising in the tourism industry. Tourism Management, 29, 221-236. http://dx.doi.org/10.1016/j.tourman.2007.03.020

\section{Copyrights}

Copyright for this article is retained by the author(s), with first publication rights granted to the journal.

This is an open-access article distributed under the terms and conditions of the Creative Commons Attribution license (http://creativecommons.org/licenses/by/3.0/). 